\title{
Sequence variation of block III segment identifies three distinct lineages within Eggplant mottled dwarf virus isolates from Italy, Spain and Greece
}

\author{
G. PARRELLA, B. GRECO
}

Istituto per la Protezione Sostenibile delle Piante (IPSP), Consiglio Nazionale delle Ricerche (CNR), UOS di Portici, Via Università 133, 80055 Portici (Napoli), Italy

Received June 4, 2015; accepted February 3, 2016

\begin{abstract}
Summary. - Partial polymerase (L) gene sequences of 919 nts, including the conserved segments pre-motif A and motif A of block III, of 20 Eggplant mottled dwarf virus (EMDV) isolates were generated, and trimmed sequences of $889 \mathrm{nts}$, based on the length of available sequences of other isolates, were used to determine phylogenetic relationships. Phylogenetic reconstructions revealed two divergent lineages, designated as genetic group A (Italian isolates) and group B, with the latter further divided into subgroups BI (Greek isolates) and BII (Spanish isolates). No evidence of recombination signals among sequences was detected, whereas analysis of the nonsynonymous/synonymous ratio indicated strong purifying selection, with codons under negative selection uniformly distributed along the sequences. An RT-PCR-RFLP method able to discriminate EMDV isolates of the two main genetic groups was proposed.
\end{abstract}

Keywords: EMDV; L gene; phylogenetic relationships; genetic variation; RFLP analysis

\section{Introduction}

Eggplant mottled dwarf virus (EMDV) is a plant rhabdovirus (the family Rhabdoviridae) belonging to the genus Nucleorhabdovirus, comprising rhabdoviruses that replicate in the host cell nucleus (Jackson et al., 2005). The virus is transmitted by leafhoppers Anaceratogallia laevis, A. ribauti and Agallia vorobjevi (Della Giustina et al., 2000; Babaie and Izadpanah, 2003), but the mode of transmission remains unclear. The natural host range of EMDV includes crops, ornamentals, and wild species (Roggero et al., 1995; Martelli et al., 2011). The viral genome is composed of a single-stranded negative-sense RNA encapsidated in bacilliform particles, wrapped by a phospholipid membrane (Martelli et al., 2011). Recently, genomic structure of two eggplant EMDV isolates, from Greece and Iran, was determined (Pappi et al., 2013; Babaie et al., 2014). Both genomes consist of approximately $13 \mathrm{~kb}$, encoding seven

E-mail: giuseppe.parrella@ipsp.cnr.it; phone: +39-081-7753658. Abbreviations: EMDV = Eggplant mottled dwarf virus; RFLP = restriction fragment length polymorphism open-reading-frames (ORFs) in the order 3'-leader-N-X-P-YM-G-L-trailer-5', corresponding to nucleocapsid (N), X protein $(\mathrm{X})$, phosphoprotein $(\mathrm{P}), \mathrm{Y}$ protein $(\mathrm{Y})$, matrix protein $(\mathrm{M})$, glycoprotein $(\mathrm{G})$ and RNA-dependent RNA polymerase (L), respectively (Pappi et al., 2013; Babaie et al., 2014).

To date, genetic characterization of EMDV isolates has been based on the molecular analysis of a short segment of the glycoprotein (G) gene of Greek isolates (Katis et al., 2011). Variability among EMDV isolates from other countries remains unknown. Here we generated partial L gene sequences of EMDV isolates from Italy and Spain and determined phylogenetic relationships among EMDV isolates, including those obtained from GenBank in August 2014. The amplified fragment encompassed the two highly conserved segments, pre-motif A and motif A, characteristic of block III of the rhabdovirus L polymerase gene (Fig. 1a) (Bourhy et al., 2005).

\section{Materials and Methods}

The 20 EMDV isolates (including seven Italian, five Spanish isolates, six Greek and one Iranian isolate) that were included in 
this study are listed in Table 1 along with geographic origin, host source, year of identification and sequence accession number. The presence of EMDV in the original hosts was confirmed by antigen-coated plate (ACP)-ELISA, using a polyclonal antiserum, kindly provided by Dr. B.E.L. Lockhart (Danesh and Lockhart, 1989), or by immuno-electron microscopy tests (De Stradis et al., 2008; Parrella et al., 2013). Total RNA was extracted from leaves of the original infected hosts using the E.Z.N.A. Plant RNA kit (Omega Bio-Tek, Norcross, GA, USA). The final RNA pellet was dissolved in RNase-free water and stored at $-80^{\circ} \mathrm{C}$. Conventional RT-PCR was carried out with primers EMDV-P1 [5'-GAT GGGGGAATGGAAAAGATG-3'; messenger sense; position 15-35] and EMDV-P2 [5'-CAGTCACAGGATCCGCAGTCA-3'; genomic sense; position 933-913], designed on the partial sequence of the $\mathrm{L}$ gene of an EMDV-Egg isolate from Greece (Acc. No. AM922322) to amplify a fragment of $919 \mathrm{bp}$, located approximately in the middle of the 3' end of the EMDV L gene (Fig. 1a). First strand reactions were performed using the Improm-II ${ }^{\mathrm{TM}}$ Reverse Trascription System (Promega, USA), following the manufacturer's instructions. Amplification was performed with the Dream $\mathrm{Taq}^{\mathrm{TM}}$ polymerase (Thermo Fisher Scientific, USA) and under the following cycling conditions (Techne Genius, Merck): initial denaturation at $94^{\circ} \mathrm{C}$ for $2 \mathrm{~min}, 35 \mathrm{cycles}$ of $94^{\circ} \mathrm{C}$ for $45 \mathrm{sec}, 54^{\circ} \mathrm{C}$ for $40 \mathrm{sec}, 72^{\circ} \mathrm{C}$ for 1 min, and final extension at $72^{\circ} \mathrm{C}$ for $10 \mathrm{~min}$. PCR products were inserted into pGEM-T vector (Promega, USA) and sequenced on both strands at MWG (Ebersberg, Germany). Obtained consensus

Table 1. Isolates of eggplant mottle dwarf virus used in the study

\begin{tabular}{|c|c|c|c|c|c|}
\hline Virus isolate & $\begin{array}{c}\text { Country } \\
\text { (region/location) }\end{array}$ & $\begin{array}{l}\text { Natural host } \\
\text { (variety) }\end{array}$ & Year of identification & Acc. No. & Reference \\
\hline $\mathrm{C} 1$ & $\begin{array}{c}\text { Italy } \\
\text { (Calabria/Guardavalle Marina) }\end{array}$ & Hibiscus rosa sinensis & 2010 & HG916814 & This study \\
\hline $\mathrm{C} 2$ & $\begin{array}{c}\text { Italy } \\
\text { (Calabria/Guardavalle Marina) }\end{array}$ & Hibiscus rosa sinensis & 2010 & HG916815 & This study \\
\hline SOM-1 & $\begin{array}{c}\text { Italy } \\
\text { (Campania/Portici) }\end{array}$ & Solanum melongena & 2011 & HG916816 & This study \\
\hline SOM-2 & $\begin{array}{c}\text { Italy } \\
\text { (Campania/Scafati) }\end{array}$ & Solanum melongena & 2011 & HG916817 & This study \\
\hline SOM-3 & $\begin{array}{c}\text { Italy } \\
\text { (Campania/Castel Volturno) }\end{array}$ & Solanum melongena & 2013 & HG916818 & This study \\
\hline SOL-1 & $\begin{array}{c}\text { Italy } \\
\text { (Campania/Somma Vesuviana) }\end{array}$ & Solanum lycopersicum & 2010 & HG916819 & This study \\
\hline $\mathrm{COV}-1$ & $\begin{array}{c}\text { Italy } \\
\text { (Emilia Romagna) }\end{array}$ & Codiaeum variegatum & 2012 & HG916820 & Parrella et al., 2012 \\
\hline Agapanthus & Italy & Agapanthus sp. & 2012 & KJ082087 & Zhai et al., 2014 \\
\hline S1 & $\begin{array}{c}\text { Spain } \\
\text { (Andalucia/Caletas de Velez) }\end{array}$ & Hibiscus rosa sinensis & 2011 & HG916821 & This study \\
\hline S2 & $\begin{array}{c}\text { Spain } \\
\text { (Andalucia/Torre del Mar) }\end{array}$ & Hibiscus rosa sinensis & 2011 & HG916822 & This study \\
\hline S3 & $\begin{array}{c}\text { Spain } \\
\text { (Andalucia/Algarrobo Costa) }\end{array}$ & Hibiscus rosa sinensis & 2011 & HG916823 & This study \\
\hline S4 & $\begin{array}{c}\text { Spain } \\
\text { (Andalucia/La Herradura) }\end{array}$ & Hibiscus rosa sinensis & 2011 & HG916824 & This study \\
\hline S5 & $\begin{array}{c}\text { Spain } \\
\text { (Andalucia/Almeria) }\end{array}$ & Cucumis sativus & 2013 & HG916825 & This study \\
\hline EMDV-Egg & Greece & Solanum melongena & 2007 & AM922322 & Direct submission \\
\hline EG1035 & $\begin{array}{c}\text { Greece } \\
\text { (Macedonia/Thessaloniki) }\end{array}$ & Solanum melongena & 2009 & FR751552 & Pappi et al., 2013 \\
\hline EMDVpit & $\begin{array}{c}\text { Greece } \\
\text { (Macedonia/Thessaloniki) }\end{array}$ & Pittosporum tobira & 2013 & HG794531 & Pappi et al., 2015 \\
\hline EMDVcs & $\begin{array}{c}\text { Greece } \\
\text { (Macedonia/Thessaloniki) }\end{array}$ & Cucumis sativus & 2013 & HG794532 & Pappi et al., 2015 \\
\hline EMDVcaps & $\begin{array}{c}\text { Greece } \\
\text { (South Aegean/Rhodes) }\end{array}$ & Capparis spinosa & 2013 & HG794533 & Pappi et al., 2015 \\
\hline EMDVnt & $\begin{array}{c}\text { Greece } \\
\text { (East Macedonia and Thrace/ } \\
\text { Komotini) }\end{array}$ & Nicotiana tabacum & 2013 & HG794534 & Pappi et al., 2015 \\
\hline Iran/SH-eg & Iran & Solanum melongena & 2011 & КС905081 & Babaie et al., 2014 \\
\hline
\end{tabular}


sequences were submitted to GenBank (Table 1). RFLP analysis was performed on the $919 \mathrm{bp}$ PCR products $(6-7 \mu \mathrm{l})$ of the Italian $(\mathrm{C} 1$, C2, SOM-1, SOM-2, SOM-3 and SOL-1) and Spanish (S1, S2, S3, S4 and S5) EMDV isolates, incubated with the restriction endonuclease TfiI according to the manufacturer's suggestions (New England BioLabs, Ipswich, MA, USA). Fragments were separated on a $6 \%$ polyacrylamide gel (acrylamide:bisacrylamide 29:1) in TAE buffer and stained with ethidium bromide. In silico restriction analysis with TfII and XbaI was further performed to compare restriction profiles of the Italian and Spanish isolates with those of the Greek and Iranian isolates (EMDV-Egg, EMDVnt, EMDVpit, EG1035, EMDVcs, EMDVcaps and Iran/SH-eg, respectively) available in GenBank. To perform the in silico restriction analysis, sequences were trimmed to match the shortest sequence (i.e. $889 \mathrm{nts}$ ).

Alignment of 889-nt fragment of the partial L gene sequences from 20 EMDV isolates (Table 1) was generated using ClustalW and phylogenetic trees were constructed by the maximum-likelihood, maximum-parsimony and neighbor-joining methods implemented in MEGA software version 6 (Tamura et al., 2013). The best fitmodel was T92+G (Tamura 3-parameters + discrete Gamma distribution) and bootstrap analysis consisted of 1,000 replicates (Tamura et al., 2013). Potato yellow dwarf virus (Acc. No. NC_016136) was used as outgroup in phylogenetic reconstruction. Pairwise nucleotide distance ( $p$-distance) comparisons among sequences were computed using the T92+G model in MEGA version 6 (Tamura et al., 2013). The pairwise nucleotide and amino acid sequence identity scores were represented as color-coded blocks using SDT v.1 software (Muhire et al., 2013). Detection of recombinations was performed using multiple methods implemented in RDP3 version 3.44b (Martin et al., 2010) with default parameters (except the choices of "linear sequence" and of "disentangling overlapping signals") and with the GARD program (Kosakovsky et al., 2006).

(a)

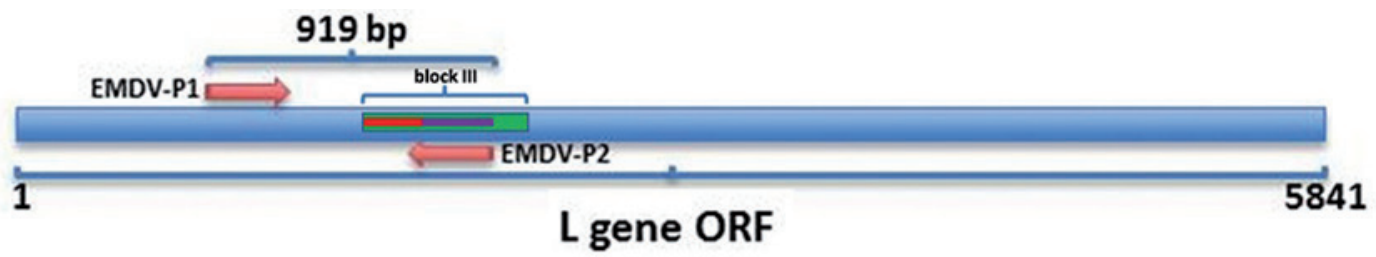

(b)

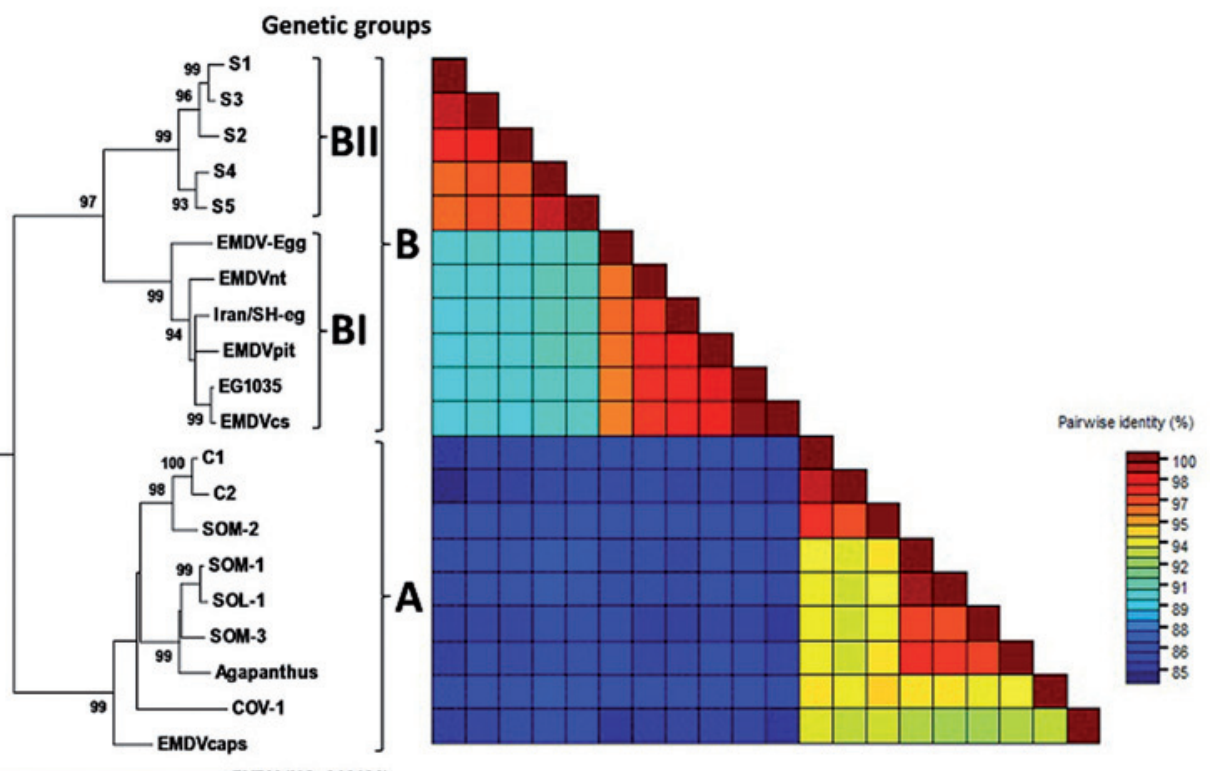

PYDV (NC_016136)

Fig. 1

Primers position, phylogenetic relationships and sequence pairwise identity of the EMDV isolates

(a) Schematic representation of relative position of the EMDV-P1/EMDV-P2 primers within the L gene. The location of the two conserved motifs, pre-motif A and motif A (red and violet bars, respectively), in the block III (green bar) is also indicated. (b) Maximum-likelihood phylogenetic tree of nucleotide sequences of the partial L genes of EMDV isolates characterized in this study with those available in the GenBank database, and graphical representation of pairwise nucleotide identity (with percentage identity scale). The EMDV isolates segregate into three distinct clades, namely A, BI and BII essentially according to their geographic origin. Evolutionary analysis was conducted using MEGA6 and figure showing pairwise nucleotide identity was obtained with SDT v.1 software. Origin of viral isolates, their acronyms and GenBank Acc. Nos. are listed in Table 1. Potato yellow dwarf virus (Acc. No. NC_016136) was used as outgroup in phylogenetic reconstruction. 
Selective pressure on each codon was evaluated using the difference between nonsynonymous $\left(d_{\mathrm{N}}\right)$ and synonymous $\left(d_{\mathrm{S}}\right)$ substitution rates per codon using the single-likelihood ancestor counting (SLAC), fixed-effects likelihood (FEL) and internal branches fixed-effects likelihood (IFEL) methods, available at Datamonkey webserver (http://www.datamonkey.org) (Kosakovsky and Frost 2005; Delport et al., 2010). Sequences were further analysed using pDRAW32 program v. 1.1.122 (AcaClone software) to identify restriction endonucleases that would result in banding patterns corresponding to phylogenetic grouping.

\section{Results and Discussion}

Phylogenetic analysis of EMDV isolates resulted in well-resolved trees with the same topology. A maximumlikelihood phylogenetic tree generated from the alignment of 20 EMDV sequences of the partial L genes is shown in Fig. 1b. The tree revealed segregation of EMDV isolates into two main lineages, here referred to as groups A and B. Group A was composed of the isolates from Italy, with the only exception of EMDVcaps, which was isolated in Greece from Capparis spinosa (Katis et al., 2011). Group B segregated into two further subgroups (sister clades): BI, consisting of five isolates from Greece and the Iranian isolate Iran/SH-eg, and BII, containing all Spanish isolates. The majority of EMDV isolates are thus arranged in three clades according to the country of origin. This suggests that geographic isolation could be one of the main determinant factors in phylogenetic divergence of EMDV, although more isolates from different countries should be analysed to validate this hypothesis.

The pairwise sequence identity among all EMDV isolates ranged from 84.0 to $99.7 \%$ at nucleotide level (Fig. 1b) and from 94.9 to $100 \%$ at the amino acid level (not shown). Pairwise sequence identities among and within the three genetic groups were: A vs BI, 84.6 to $86.3 \%$ at nucleotide level and 97.3 to $99.3 \%$ at the amino acid level; A vs BII, 84.0 to $86.8 \%$ at nucleotide level and 94.9 to $98.3 \%$ at the amino acid level; BI vs BII, 89.8 to $90.7 \%$ at nucleotide level and 96.3 to $99.0 \%$ at the amino acid level; within A, 92.6 to $99.0 \%$ at nucleotide level and 97.3 to $100 \%$ at the amino acid level; within BI, 95.9 to $99.7 \%$ at nucleotide level and 98.6 to $100 \%$ at the amino acid level; within BII, 96.4 to $98.9 \%$ at nucleotide level and 97.3 to $99.3 \%$ at the amino acid level. Based on the frequency of the $L$ gene partial sequence pairs with similar identity score at $1 \%$ identity intervals, one major peak (not shown) was observed at $85 \%$, within $84-87 \%$ of percentage of pairwise identity interval between $\mathrm{A}$ and $\mathrm{B}$ genetic groups. This suggests that an identity score of $84 \%$ should be used as a threshold for differentiation between groups $\mathrm{A}$ and $\mathrm{B}$.

The mean sequence distance of the partial $L$ genes within group A and B was 0.055 and 0.070 , respectively, while be- tween the two groups mean sequence distance was 0.164 . The mean distance between BI and BII was 0.107 , and nearly the same between A and the two subgroups BI and BII, 0.162 (A vs BII) and 0.167 (A vs BI), respectively. The $p$-distance values between groups $A$ and $B$ were statistically significant $(\mathrm{p} \leq 0.05)$.

No recombination signal was detected in the alignment by six independent methods implemented in RDP3 ( $\mathrm{p} \leq 0.05)$ and by GARD program. The selection pressure $\left(d_{\mathrm{N}} / d_{\mathrm{s}}\right)$ was nearly the same for the three methods used: 0.038 for SLAC and 0.039 for IFEL and FEL with 34, 53 and 91 codons, respectively, of a total of 296 , detected to be under negative selection at 0.05 significance level. Codons under purifying (negative) selection were equally scattered along the sequence, both along the two conserved motifs of the block III of the L gene (pre-motif A and motif A) and on the remaining part of the sequence (not shown). Since no recombination signals were detected, negative (purifying) selection is the main force of virus evolution for the portion of the $\mathrm{L}$ gene analyzed. No codons were found to be under positive selection. Even though the L protein tends to be less divergent than other plant rhabdovirus proteins (Pappi et al., 2013), phylogenetic analysis of the partial L EMDV gene defined three genetic groups according to geographic origin. The exceptions, Greek isolate EMDVcaps, which grouped with Italian isolates, and the Iranian isolate Iran/SH-Eg, which grouped with Greek isolates (Fig. 1b), suggest some gene flow among regions. A slight molecular divergence was already observed between Greek mainland isolates and the EMDVcaps isolate from the Rhodes Island by Katis et al. (2011). EMDVcaps isolate was probably introduced accidentally in the Rhode Island, where the geographic isolation has contributed to the maintenance of genetic diversity between the Greek isolates from the island and the mainland. Results are similar to those reported for the Taro vein chlororis virus, an aphid-transmitted plant rhabdovirus, whose phylogenetic grouping of isolates $(n=20)$ based on the L gene variability also reflected geographical origin, with some exceptions (Revill et al., 2005).

In silico endonuclease restriction analysis of partial L gene sequences indicated that the restriction enzymes TfiI and the $X b a I$ could generate specific profiles for each genetic group. In particular, TfiI was able to distinguish EMDV isolates belonging to the two major lineages (i.e., groups A and B) and was tested in vitro on the Italian (group A) and Spanish isolates (group BII) (Fig. 2). Since most sequences of Greek isolates obtained from GeneBank database were shorter $(889$ bp) than the sequences obtained in this study, the effectiveness of TfiI to produce the RFLP pattern expected for the genetic group B was confirmed by in silico RFLP analysis on trimmed sequences alignment (Table 2). In addition, $\mathrm{XbaI}$ in silico restriction analysis produced a specific profile for Greek isolates (group BI), consisting in two fragments of 823 and 


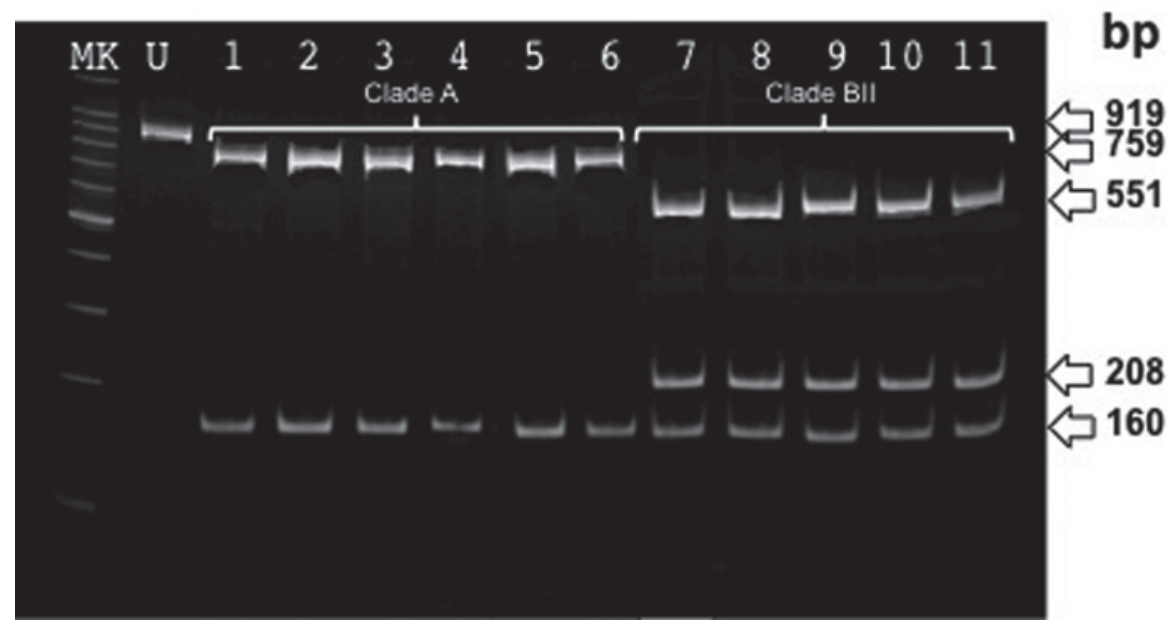

Fig. 2

Restriction profiles obtained after digestion with the TfiI endonuclease of the $919 \mathrm{bp}$ amplicons of EMDV isolates belonging to phylogenetic groups $\mathrm{A}$ and $\mathrm{BII}$, respectively

MK = 100 bp ladder (Promega, USA), U = undigested control, 1-6 = Italian EMDV isolates (C1, C2, SOM-1, SOM-2, SOM-3 and SOL-1), 7-11 = Spanish isolates (S1, S2, S3, S4 and S5). The Italian isolate COV-1 (Table 1), not included in the gel, confirmed the expected profiles for isolates belonging to the genetic group A after in silico restriction analysis (not shown).

Table 2. Predicted restriction profiles of partial $L$ sequences (889 bp) obtained with $T f i$ and $X b a I$ endonucleases (TfiI allows the discrimination between clades A and B (consisting of BI and BII subclades), while the $\mathrm{XbaI}$ site was detected specifically in Greek isolates of EMDV)

\begin{tabular}{|c|c|c|c|c|}
\hline \multirow[b]{2}{*}{ Clades } & \multicolumn{2}{|c|}{$T f i I$} & \multicolumn{2}{|c|}{$X b a I$} \\
\hline & No. of cuts & $\begin{array}{l}\text { Fragments } \\
\text { size }\end{array}$ & No. of cuts & $\begin{array}{l}\text { Fragments } \\
\text { size }\end{array}$ \\
\hline A & 1 & 738,151 & 0 & 889 \\
\hline BI & 2 & $530,208,151$ & 1 & 823,66 \\
\hline BII & 2 & $530,208,151$ & 0 & 889 \\
\hline
\end{tabular}

$66 \mathrm{bp}$, while sequences belonging to groups A and BII were not digested (Table 2). Thus, all the three genetic groups can be easily identified using restriction profile analysis.

In conclusion, this study represents the first molecular evidence of genetic diversity existing among the EMDV isolates from at least three Mediterranean countries. Nevertheless, the characterization of additional isolates, also from other geographic areas, and the analysis of different genes, in addition to the $\mathrm{L}$ gene, are also recommended for a better understanding of the genetic structure and variation of EMDV isolates in a large geographical scale.

Acknowledgements. The authors wish to thank Dr. Jesus NavasCastillo (IHSM-CSIC, Malaga, Spain) for providing the EMDV Spanish isolates and Dr. Anna Giulia Nappo (IPSP-CNR, Portici, Italy) for invaluable technical assistance. Dr. Barbara Greco was supported by National Research Council (CNR, Italy) with a grant.
Research partially supported by the Campania Region, Italy (2013 Plan of Phytosanitary Actions).

\section{References}

Babaie G, Izadpanah K (2003): Vector transmission of Eggplant mottled dwarf virus in Iran. J. Phytopathol. 151, 679-682. http://dx.doi.org/10.1046/j.1439-0434.2003.00788.x

Babaie G, Habibi MK, Massah A, Dizadji A, Izadinejad L, Simon A (2014): Complete genome sequence and genome analysis of Eggplant mottled dwarf virus-Iranian Isolate. J. Phytopathol. 163, 331-341. http://dx.doi.org/10.1111/jph.12256

Bourhy H, Cowley JA, Larrous F, Holmes EC, Walker PJ (2005): Phylogenetic relationships among rhabdoviruses inferred using the L polymerase gene. J. Gen. Virol. 86, 2849-2858. http://dx.doi.org/10.1099/vir.0.81128-0

Danesh D, Lockhart BEL (1989): Eggplant mottled dwarf virus in potato in Iran. Plant Dis. 73, 856-858. http://dx.doi. org/10.1094/PD-73-0856

Della Giustina W, Javoy M, Bansept P, Morel E, Balasse H, Goussard N, Passard C (2000): Les cicadelles du genre Anacertagallia vectrice du virus responsible de la maladie de la peau de crapaud du concombre. PHM, Rev. Hort. 420, 40-43.

Delport W, Poon AF, Frost SDW, Kosakovsky SLP (2010): Datamonkey 2010: a suite of phylogenetic analysis tools for evolutionary biology. Bioinformatics 26, 2455-2457. http://dx.doi.org/10.1093/bioinformatics/btq429

De Stradis A, Parrella G, Vovlas C, Ragozzino A (2008): Vein yellowing of Hibiscus rosa-sinensis caused by Eggplant mottled dwarf virus in southern Italy. J. Plant. Pathol. 90, 359-361. 
Jackson AO, Dietzgen RG, Goodin MM, Bragg JN, Deng M (2005): Biology of plant Rhabdoviruses. Annu. Rev. Phytopathol. 43, 623-660. http://dx.doi.org/10.1146/annurev. phyto.43.011205.141136

Katis NI, Chatzivassiliou EK, Clay CM, Maliogka VI, Pappi P, Efthimiou K, Dovas CI, Avgelis AD (2011): Development of an IC-RT-PCR assay for the detection of Eggplant mottled dwarf virus and partial characterization of isolates from various hosts in Greece. J. Phytopathol. 93, 353-362.

Kosakovsky SLP, Frost SDW (2005): Datamonkey: rapid detection of selective pressure on individual sites of codon alignments. Bioinformatics 21, 2531-2533. http://dx.doi. org/10.1093/bioinformatics/bti320

Kosakovsky PSL, Posada D, Gravenor MB, Woelk CH, Frost SDW (2006): GARD: a genetic algorithm for recombination detection. Bioinformatics 22, 3096-3098. http://dx.doi. org/10.1093/bioinformatics/btl474

Martelli GP, Russo M, Rubino L (2011): Eggplant mottle dwarf virus. In Description of Plant Viruses. No. 421, Association of Applied Biologist. Available online in http://www.dpvweb. net/dpv/showdpv.php?dpvno $=421$

Martin DP, Lemey P, Lott M, Moulton V, Posada D, Lefeuvre P (2010): RDP3: a flexible and fast computer program for analyzing recombination. Bioinformatics $26,2462-2463$. http://dx.doi.org/10.1093/bioinformatics/btq467

Muhire B, Martin DP, Brown JK, Navas-Castillo J, Moriones E, Zerbini FM, Rivera-Bustamante R., Malathi VG, Briddon RW, Varsani A (2013): A genome-wide pairwiseidentity-based proposal for the classification of viruses in the genus Mastrevirus (family Geminiviridae). Arch. Virol. 158, 1411-1424. http://dx.doi.org/10.1007/s00705$\underline{012-1601-7}$

Pappi PG, Dovas CI, Efthimiou K, Maliogka VI, Katis NI (2013): A novel strategy for the determination of a rhabdovirus genome and its application to sequencing of Eggplant mottled dwarf virus. Virus Genes 47, 105-113. http:// dx.doi.org/10.1007/s11262-013-0911-5

Pappi PG, Chaintoutis SC, Dovas CI, Efthimiou KE, Katis NI (2015): Development of one-tube real-time qRT-PCR and evaluation of RNA extraction methods for the detection of Eggplant mottled dwarf virus in different species. J. Virol. Methods 212, 59-65. http://dx.doi.org/10.1016/j. jviromet.2014.11.001

Parrella G, Greco B, De Stradis A, Cavicchi L, Bellardi MG (2012): Serological and molecular evidence that Croton vein yellow virus is an isolate of Eggplant mottled dwarf virus. J. Plant. Pathol. 94, 73.

Parrella G, De Stradis A, Greco B, Villanueva F, Fortes IM, NavasCastillo J (2013): First report of Eggplant mottled dwarf virus in China rose in southern Spain. Span. J. Agr. Res. 11, 204-207. http://dx.doi.org/10.5424/sjar/2013111-3461

Revill P, Trinh X, Dale J, Harding R (2005): Taro vein chlorosis virus: characterization and variability of a new nucleorhabdovirus. J. Gen. Virol. 86, 491-499. http://dx.doi. org/10.1099/vir.0.80591-0

Roggero P, Milne RG, Masenga V, Ogliara P (1995): First report of Eggplant mottled dwarf rhabdovirus in cucumber and pepper. Plant Dis. 79, 321. http://dx.doi.org/10.1094/ PD-79-0321C

Tamura K, Stecher G, Peterson D, Filipski A, and Kumar S (2013): MEGA6: Molecular Evolutionary Genetics Analysis Version 6.0. Mol. Biol. Evol. 30, 2725-2729. http://dx.doi. org $/ 10.1093 / \mathrm{molbev} / \mathrm{mst} 197$

Zhai Y, Miglino R, Sorrentino R, Masenga V, Alioto D, Pappu HR (2014): First report of natural infection of Agapanthus sp. by Eggplant mottled dwarf virus (EMDV). New Dis. Rep. 29, 20. http://dx.doi.org/10.5197/j.2044-0588 .2014 .029 .020 